\title{
Synthesis of novel acridine bis-sulfonamides with effective inhibitory activity against the carbonic anhydrase isoforms I, II, IX and XII
}

\author{
Ibrahim Esirden ${ }^{\mathrm{a}}$, Ramazan Ulus ${ }^{\mathrm{a}}$, Burak Aday $^{\mathrm{a}}$, Muhammet Tanç ${ }^{\mathrm{b}}$, Claudiu T. Supuran ${ }^{\mathrm{b}, *}$, \\ Muharrem Kaya ${ }^{\mathrm{c}, *}$ \\ ${ }^{a}$ Chemistry Department, Faculty of Arts and Science, Dumlupinar University, 43100 Kütahya, Turkey \\ ${ }^{\mathrm{b}}$ Università degli Studi di Firenze, NEUROFARBA Dept., Sezione di Scienze Farmaceutiche e Nutraceutiche, 50019 Sesto Fiorentino (Florence), Italy \\ ${ }^{\mathrm{c}}$ Biochemistry Department, Faculty of Arts and Science, Dumlupınar University, 43100 Kütahya, Turkey
}

\section{A R T I C L E I N F O}

\section{Article history:}

Received 20 July 2015

Revised 10 September 2015

Accepted 14 September 2015

Available online 15 September 2015

\section{Keywords:}

Carbonic anhydrase

Acridine

Sulfonamide

Enzyme inhibition

Isoforms CA I, II, IX and VII

\begin{abstract}
A B S T R A C T
By using a multi component reaction system (MCR), nitro acridine sulfonamides were obtained from cyclic-1,3-diketones, 4-aminobenzene sulfonamide and aromatic aldehydes. Some novel acridine bissulfonamides 6a-1 were then synthesized by the reaction between sulfonyl chlorides and the novel amino-acridine sulfonamides $\mathbf{5} \mathbf{a}$ and $\mathbf{5 b}$, obtained by reduction of nitro-acridine sulfonamide derivatives 4a and $\mathbf{4 b}$. The newly synthesized compounds were investigated as inhibitors of 4 human carbonic anhydrase isoforms (hCA, EC 4.2.1.1). Several of the compounds showed low micromolar inhibition against the medically relevant isoforms hCA I, II, IX, and XII.
\end{abstract}

(c) 2015 Elsevier Ltd. All rights reserved.

\section{Introduction}

Acridines are planar tricyclic aromatic compounds which contain nitrogen in the heterocyclic ring. Even if these heterocycles were discovered the 19th century, some of their derivatives are still under investigation. Acridine shows a similarity in its structure to nicotinamide adenine dinucleotide (NADH), ${ }^{1}$ a molecule

\footnotetext{
Abbreviations: MCR, multi component reaction; CA, carbonic anhydrase; hCA human carbonic anhydrase; $\mathrm{NADH}$, nicotinamide adenine dinucleotide; Amsacrine, $\mathrm{N}$-[4-(acridin-9-ylamino)-3-methoxyphenyl]methanesulfonamide; Asulacrine, 9[4-(methanesulfonamido)-2-methoxyanilino]- $N, 5$-dimethylacridine-4-carboxamide; Acronycine, 6-methoxy-3,3,12-trimethylpyrano[2,3-c]acridin-7-one; DACA $\mathrm{N}$-[2-(dimethylamino)ethyl]acridine-4-carboxamide; Proflavine, acridine-3,6-diamine; Ascididemin, 9H-quino[4,3,2-de][1,10]phenanthrolin-9-one; CAIs, carbonic anhydrase inhibitors; IR, infrared; NMR, nuclear magnetic resonance; HRMS, high resolution mass spectroscopy; SAR, structure-activity relationship; DMSO, dimethy sulfoxide; LC, liquid chromatography; DBSA, p-dodecylbenzenesulfonic acid; TLC tine layer chromatography; mp, melting point; Lit, literature; ESI, electron spray ionization; TEA, trimethylamine; $\mu \mathrm{M}$, micromolar; $\mathrm{nM}$, nanomolar; $K_{\mathrm{J}}$, inhibition constant.

* Corresponding authors. Tel.: +39 055457 3005; fax: +39 0554573385 (C.T.S.) tel.: +90 2742652051 ; fax: +90 2742652056 (M.K.).

E-mail addresses: claudiu.supuran@unifi.it (C.T. Supuran), muharrem.kaya@dpu. edu.tr (M. Kaya).
}

possessing important biological functions as a coenzyme/cofactor. ${ }^{2}$ Thus there are many acridine-like compounds showing anticancer, ${ }^{3,4}$ or antimicrobial activity, ${ }^{5}$ whereas other such derivatives were reported to act as effective $\beta$-channel opener in cardiovascular disease, ${ }^{6}$ in the photodynamic therapy, ${ }^{7}$ or as anti-Alzheimer's agents. ${ }^{8}$ Well-known drugs containing the acridine moiety include Amsacrine, Asulacrine, Acronycine, Acridine carboxamide (DACA), Proflavine and Ascididemin (Chart 1), and they have been used as anti-cancer or anti-bacterial agents. ${ }^{12,13}$ Furthermore, many acridine sulfonamides are known as strong carbonic anhydrase (CA, EC 4.2.1.1) inhibitors (CAIs), potentially useful for the treatment glaucoma $^{9,10}$ or other conditions, which the activity of the CA isoforms are deregulated. ${ }^{11}$

CAs are responsible for the reversible hydration of carbon dioxide to bicarbonate. ${ }^{11}$ By catalyzing this simple reaction CAs participate in many physiological processes such as regulation of respiration and gas exchange, bone resorption, calcification, $\mathrm{pH}$ and $\mathrm{CO}_{2}$ homeostasis, electrolyte secretion in a variety of tissues/ organs, biosynthetic reactions. ${ }^{11-13}$ This diversity of roles makes different isoforms interesting drug targets for a variety of conditions. ${ }^{14}$

The sulfonamides and their isosteres such as the sulfamates and sulfamides, are established CAIs and are in clinical use for almost 
<smiles>COc1cc(NS(C)=O)ccc1Nc1c2ccccc2nc2ccccc12</smiles>

Amsacrine<smiles>CN(C)CCNC(=O)c1cccc2cc3ccccc3nc12</smiles>

Acridine Carboxamide (DACA)<smiles>CNC(=O)c1cccc2c(Nc3ccc(N(C)C)cc3OC)c3cccc(C)c3nc12</smiles>

Asulacrine<smiles>Nc1ccc2cc3ccc(N)cc3nc2c1</smiles>

Proflavine<smiles>COc1cc2c(c3c(=O)c4ccccc4n(C)c13)CCC(C)(C)O2</smiles>

Acronycine<smiles>O=C1c2cccnc2-c2nccc3c2c1nc1ccccc13</smiles>

Ascididemin

Chart 1. Some drugs incorporating acridine moieties.

70 years for the treatment of glaucoma, obesity, epilepsy and as diuretics. ${ }^{15}$ The large use of CAIs for pharmaceutical applications relies on the wide distribution of the 15 human (h) CA isoforms within different tissues as well as on their implication in many physiological/pathological conditions. Antiglaucoma CAI-drugs mainly target CA II, IV and XII; the diuretics CA II, IV, XII and XIV; the antiepileptic CA VII and XIV. ${ }^{11,14,16,17}$ The selective inhibition of the CA IX and XII isoforms results in antitumor and antimetastatic effects. ${ }^{13,14}$ In vivo experiments showed that silencing of hCA IX reduces xenograft tumors to $40 \%$ of the volume along with up-regulation response of the gene encoding for hCA XII. Silencing of both hCA IX and hCA XII showed 85\% reduction of tumor growth. hCA IX is a $54-58 \mathrm{kDa}$ trans-membrane protein consistent of a cytoplasmic fragment, which exhibits phosphorylation sites, a trans membrane section and an extracellular region. hCA IX exposes its catalytic domain on the extracellular environment and is further functionalised with glycosidic residues. ${ }^{18}$ It should be stressed that currently a sulfonamide CA IX inhibitor (SLC0111) entered in Phase I clinical studies for the treatment of hypoxic, advanced stage metastatic solid tumors. ${ }^{19,20}$

The main drawback associated to the use of CAIs is represented by the lack of selectivity in inhibiting various isoforms by many of the first and second generation CAIs, thus resulting in a plethora of side effects. ${ }^{21,22}$ In this context many efforts have been made for the development of specific CAIs, and some remarkable results have been achieved in the last 15 years since the introduction of the tail approach. ${ }^{20-22}$ Moreover novel CAIs classes such as the polyamines, ${ }^{23}$ phenols, ${ }^{24}$ dithiocarbamates, ${ }^{25}$ xanthates, ${ }^{26}$ coumarins, thiocoumarins, 2-thioxo-coumarins and coumarin oximes ${ }^{16,27-29}$ were identified and their inhibition mechanisms of many of these compounds were determined by means of X-ray crystallography CA II adducts. ${ }^{21,24,25}$

Considering the interest in sulfonamide CAIs, in this study we investigate a new class of acridine bis-sulfonamides which have been designed by an approach of multicomponent reactions. The structure of the novel compounds was confirmed by using spectral analysis (FT-IR, ${ }^{1} \mathrm{H}$ NMR, ${ }^{13} \mathrm{C}$ NMR (APT) and HRMS) and they were investigated the inhibition of human CA isoforms hCA I, II, IX and XII. The structure-activity relationships (SAR) for the inhibition of these isoforms with the acridine bis-sulfonamides are also discussed.

\section{Results and discussion}

\subsection{Chemistry}

The general synthetic method, three steps reaction shown in Scheme 1, was used to prepare the nitro acridine derivatives (4a and $\mathbf{4 b}$ ), novel amino acridine compounds (5a and $\mathbf{5 b}$ ) and novel acridine bis-sulfonamide compounds (6a-1). For the first step MCR method applied, and compounds $\mathbf{4 a}$ and $\mathbf{4 b}$ were obtained by using dimedone (1), 4-aminobenzenesulfonamide (2), nitro aromatic aldehydes (3a and $\mathbf{3 b}$ )-molar ratio of 2:1:1 and DBSA, as phase transfer catalyst, in one-pot reaction in water. For the second step, new amino acridine derivatives ( $\mathbf{5 a}$ and $\mathbf{b}$ ) were synthesized by using excessive reduction reactive-aqueous sodium poly-sulfide-from nitro acridine compounds (4a and $\mathbf{4 b}$ ) at reflux temperature with high yields (respectively, $87 \%$ and $82 \%$ ). For the final step, the acridine bis-sulfonamide derivatives $\mathbf{6 a - 1}$ were obtained from various sulfonyl chlorides and amino acridines (5a, 5b) in THF at room temperature in presence of triethylamine (TEA). ${ }^{30,31}$

All the products were characterized by melting point detection, IR, NMR and HRMS analyses. In the IR spectra of the compounds 5a, 5b and 6a-1, the $-\mathrm{NH}_{2},-\mathrm{SO}_{2} \mathrm{NH}_{2},-\mathrm{SO}_{2} \mathrm{NHR}$ vibrations were observed in the region between 3244 and $3467 \mathrm{~cm}^{-1}$. Aliphatic $\mathrm{C}-\mathrm{H}$ stretching bands were observed at $2954-2959 \mathrm{~cm}^{-1}$ and the aromatic $\mathrm{C}-\mathrm{H}$ stretching bands were observed at 3032$3098 \mathrm{~cm}^{-1}$. Also, sharp peaks were observed for the carbonyl groups in the region between 1623 and $1634 \mathrm{~cm}^{-1}$ for all the acridine bis-sulfonamides.

For the ${ }^{1} \mathrm{H}$ NMR spectra of compounds $\mathbf{5 a}, \mathbf{5 b}$ and $\mathbf{6 a - 1}$ singlet peaks were observed between 0.60 and $0.90 \mathrm{ppm}$ which belong to protons of the methyl groups in position 3 and 6 . For the compounds $\mathbf{5 a}, \mathbf{5 b}$ and $\mathbf{6 a - 1}$ doublet or multiplet peaks were observed in between 1.62 and $2.22 \mathrm{ppm}$ belong to $\mathrm{CH}_{2}$ group protons of the cyclohexene ring. ${ }^{32}$ For the compounds $\mathbf{6 b}, \mathbf{6 e}, \mathbf{6 h}$ and $6 \mathbf{k}$ singlet peaks were observed in between 2.18 and 2.52 ppm belong to protons of the methyl group. For the compounds $\mathbf{6 c}$ and $\mathbf{6 i}$ the signal of the methoxy protons of were observed at 3.80 and $3.70 \mathrm{ppm}$, respectively. Also the signals of the $\mathrm{CH}$ protons were observed at 4.90 and $4.98 \mathrm{ppm}$ and the signals for the aromatic protons were observed between 6.30 and $8.36 \mathrm{ppm}$. For the compounds $\mathbf{5 a}, \mathbf{5 b}$ and $\mathbf{6 a}-\mathbf{1}-\mathrm{SO}_{2} \mathrm{NH}_{2}$ group protons were assigned as singlet peaks 


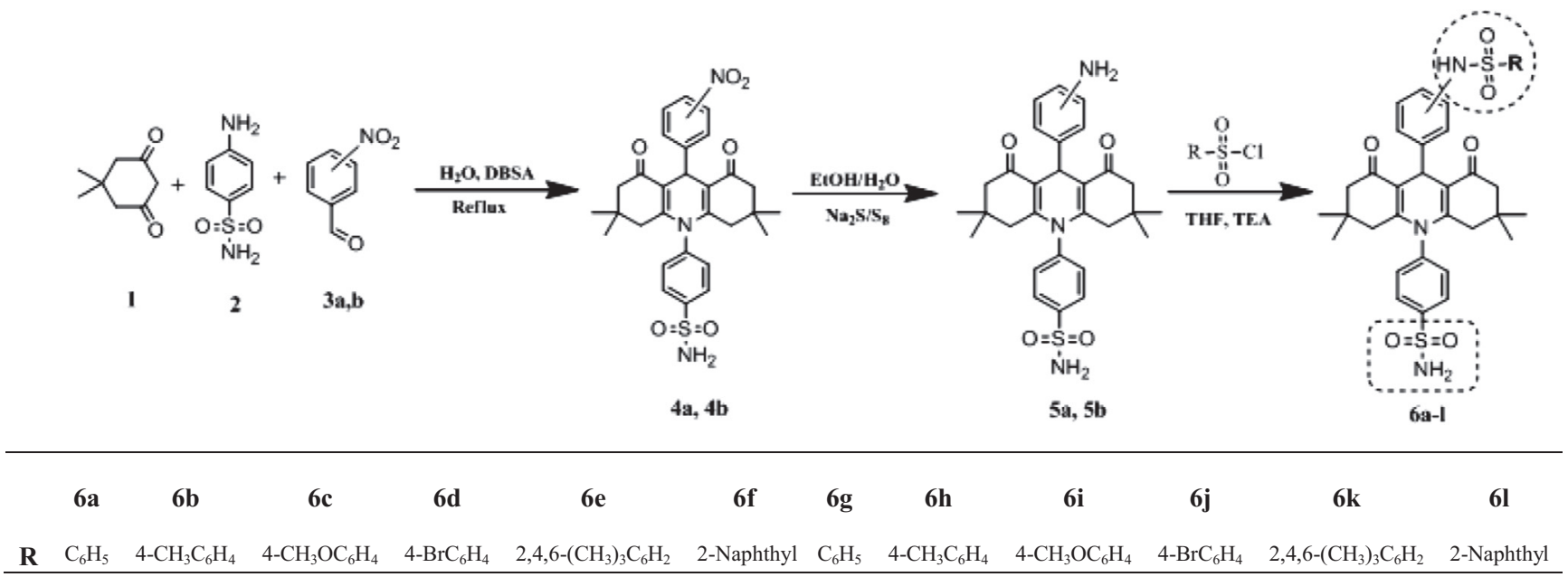

Scheme 1. Synthesis of novel acridine bis-sulfonamide compounds.

Table 1

CA inhibition data for compounds (4a, $\mathbf{4 b}),(\mathbf{5 a}, \mathbf{5 b}),(\mathbf{6 a}-\mathbf{l})$ and standard inhibitors against human isozymes hCA I, II, IX and XII by a stopped flow $\mathrm{CO}_{2}$ hydrase assay ${ }^{32}$

\begin{tabular}{llllll}
\hline \multirow{2}{*}{ Entry } & $-\mathrm{R}$ & \multicolumn{4}{c}{$K_{\mathrm{I}}(\mu \mathrm{M})$} \\
\cline { 3 - 6 } & & hCA I & hCA II & hCA IX & hCA XII \\
\hline $\mathbf{4 a}$ & - & 5.1 & 0.64 & 1.02 & 0.35 \\
$\mathbf{4 b}$ & - & 0.69 & 0.89 & 0.42 & 0.50 \\
$\mathbf{5 a}$ & - & 2.5 & 0.65 & 1.00 & 0.61 \\
$\mathbf{5 b}$ & - & 8.87 & 0.50 & 0.92 & 0.03 \\
$\mathbf{6 a}$ & $\mathrm{C}_{6} \mathrm{H}_{5}$ & 2.09 & 0.10 & 0.58 & 0.64 \\
$\mathbf{6 b}$ & $4-\mathrm{CH}_{3} \mathrm{C}_{6} \mathrm{H}_{4}$ & 4.55 & 0.96 & 0.10 & 0.53 \\
$\mathbf{6 c}$ & $4-\mathrm{CH}_{3} \mathrm{OC}_{6} \mathrm{H}_{4}$ & 6.92 & 0.37 & 0.44 & 0.92 \\
$\mathbf{6 d}$ & $4-\mathrm{BrC}_{6} \mathrm{H}_{4}$ & 6.53 & 0.60 & 1.12 & 0.86 \\
$\mathbf{6 e}$ & $2,4,6-\left(\mathrm{CH}_{3}\right)_{3} \mathrm{C}_{6} \mathrm{H}_{2}$ & 5.62 & 0.48 & 0.09 & 0.26 \\
$\mathbf{6 f}$ & $2-\mathrm{Naphthyl}$ & 3.89 & 0.47 & 0.28 & 0.37 \\
$\mathbf{6 g}$ & $\mathrm{C}_{6} \mathrm{H}_{5}$ & 8.91 & 0.38 & 0.11 & 1.02 \\
$\mathbf{6 h}$ & $4-\mathrm{CH}_{3} \mathrm{C}_{6} \mathrm{H}_{4}$ & 4.27 & 0.39 & 0.10 & 0.78 \\
$\mathbf{6 i}$ & $4-\mathrm{CH}_{3} \mathrm{OC}_{6} \mathrm{H}_{4}$ & 4.31 & 0.25 & 0.80 & 0.92 \\
$\mathbf{6 j}$ & $4-\mathrm{BrC}_{6} \mathrm{H}_{4}$ & 5.38 & 0.45 & 0.25 & 0.56 \\
$\mathbf{6 k}$ & $2,4,6-\left(\mathrm{CH}_{3}\right)_{3} \mathrm{C}_{6} \mathrm{H}_{2}$ & 6.52 & 0.43 & 0.09 & 0.52 \\
$\mathbf{6 1}$ & $2-\mathrm{Naphthyl}^{*}$ & 6.53 & 0.50 & 0.81 & 0.83 \\
AAZ & - & 0.25 & 0.012 & 0.025 & 0.006
\end{tabular}

Acetazolamide (AAZ) was used as a standard inhibitor for all CAs investigated here. $K_{\mathrm{I}}$-s are means from 3 different assays. Standard errors were in the range of $\pm 5-10 \%$ of the reported values (data not shown).

between 7.61 and $7.63 \mathrm{ppm}$ and the compounds $\mathbf{6 a - f}$ and $7 \mathbf{a}-\mathbf{f}$ were assigned as singlet peaks between 9.90 and $10.25 \mathrm{ppm}$. The ${ }^{13} \mathrm{C}$ NMR (APT) spectra of the compounds $\mathbf{5 a}, \mathbf{5 b}$ and $\mathbf{6 a}-\mathbf{l}$ displayed a signal for the carbonyl group carbon peak between 195.34 and $195.63 \mathrm{ppm}$ and the signal of carbon-carbon double bonds was observed between 113.29 and $162.67 \mathrm{ppm} .{ }^{33}$ Also, aliphatic carbon peaks were observed at 20.82-56.00 ppm. When the HRMS analyses of all the molecules (5a, $5 \mathbf{b}$ and $\mathbf{6} \mathbf{a}-\mathbf{1}$ ) were examined, we observed signals in line with the molecule ion peaks of the proposed structures.

\subsection{Carbonic anhydrase inhibition}

The new compounds reported here and the standard drug acetazolamide were assayed as inhibitors of four cytosolic human isoforms, hCA I, II, IX and XII (Table 1). ${ }^{34}$

The new derivatives were rather ineffective inhibitors of the widespread cytosolic isoform hCA I, with inhibition constants in the range of $0.69-8.91 \mu \mathrm{M}$ (acetazolamide, the standard sulfonamide CAI has a $K_{\mathrm{I}}$ of $250 \mathrm{nM}$ against this isoform). There are few important variations in order to be able to discuss SAR. It was observed that increasing of the bulkiness of the tails for the compound series $\mathbf{4 a}, \mathbf{4 b}$, and $\mathbf{6 a}-\mathbf{f}$ (Chart 2) resulted with slight increasing of $K_{\mathrm{I}}$ values, that is, decreasing on inhibitory effect, in the range of $0.69-6.92 \mu \mathrm{M}$. On the contrary the opposite effect of bulkiness was observed that for the compound series $\mathbf{5 a}, \mathbf{5 b}$, and $\mathbf{6 g}-\mathbf{l}$, (Chart 2), with inhibition constants varying in the range of $2.5-8.91 \mu \mathrm{M}$. It should be noted that position of the tails (sulfonyl groups) on the main scaffold (for $\mathbf{6 a}-\mathbf{f}$, are -para and for

$\mathrm{K}_{\mathrm{l}} \mathrm{s}$ for hCA I

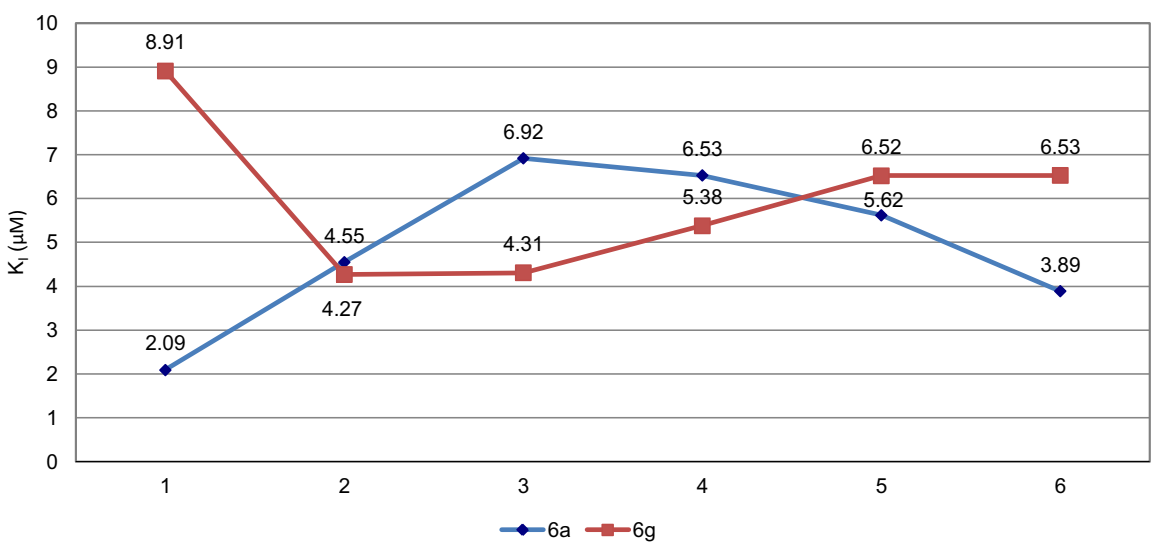

Chart 2. Change in the $K_{I}$ values for $\mathbf{6 a - f}$ (red line) and 6g-l (blue line). 


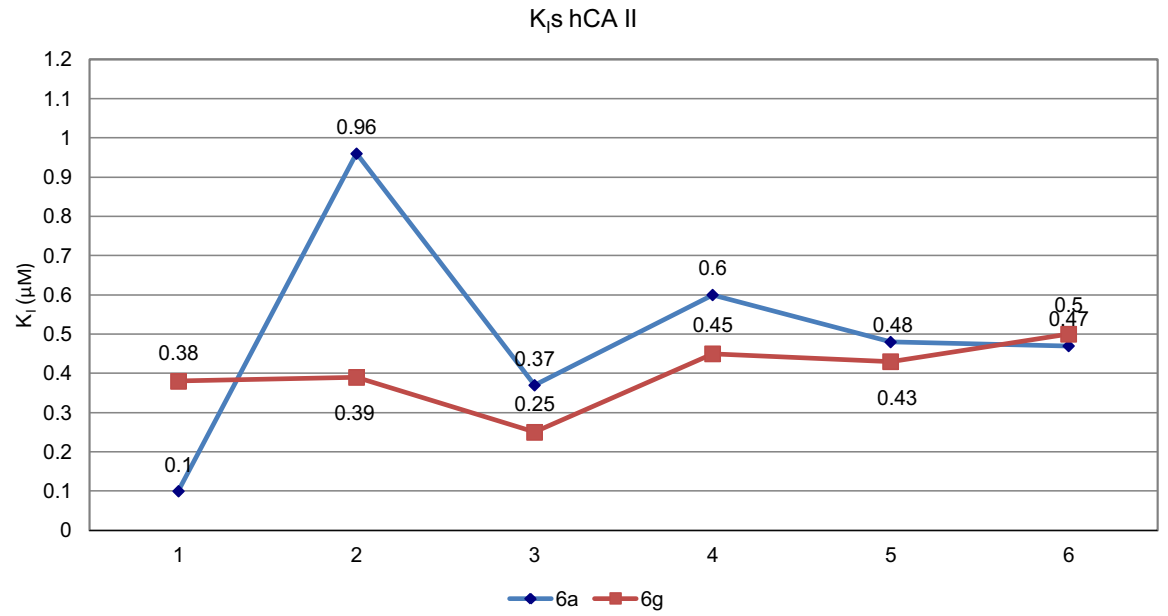

Chart 3. Change in the $K_{\mathrm{I}}$ values for $\mathbf{6 a}-\mathbf{f}$ (red line) and $\mathbf{6 g}-\mathbf{l}$ (blue line).

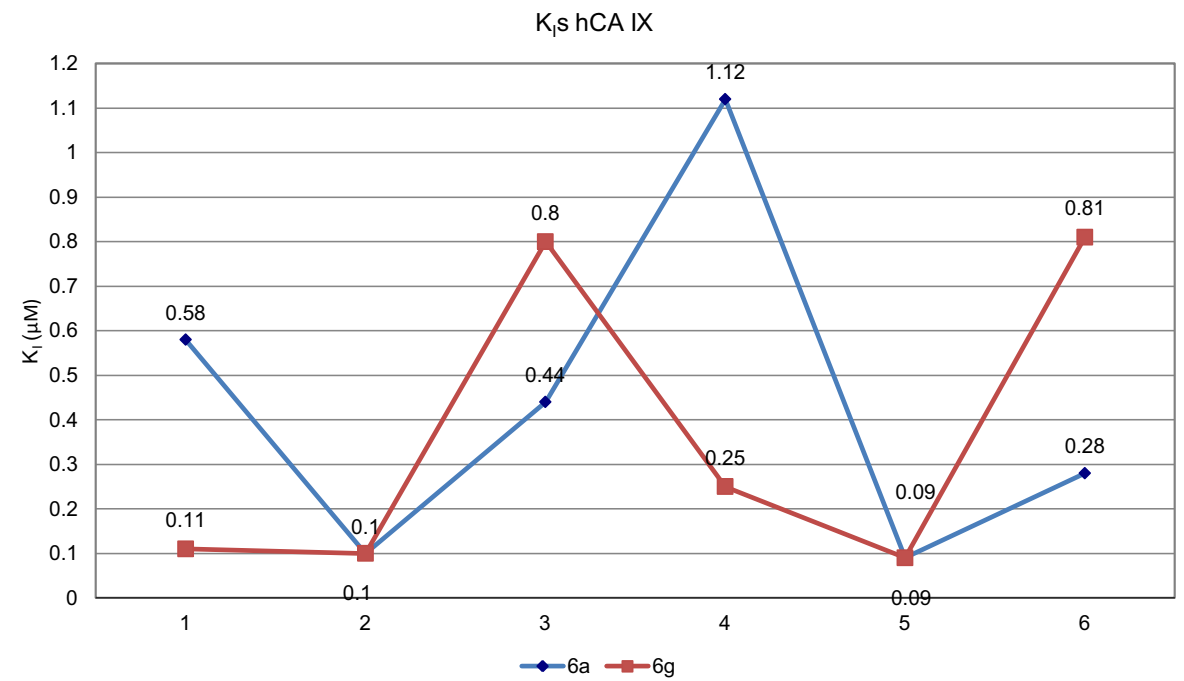

Chart 4. Change in the $K_{\mathrm{I}}$ values for $\mathbf{6 a}-\mathbf{f}$ (red line) and $\mathbf{6 g - 1}$ (blue line).

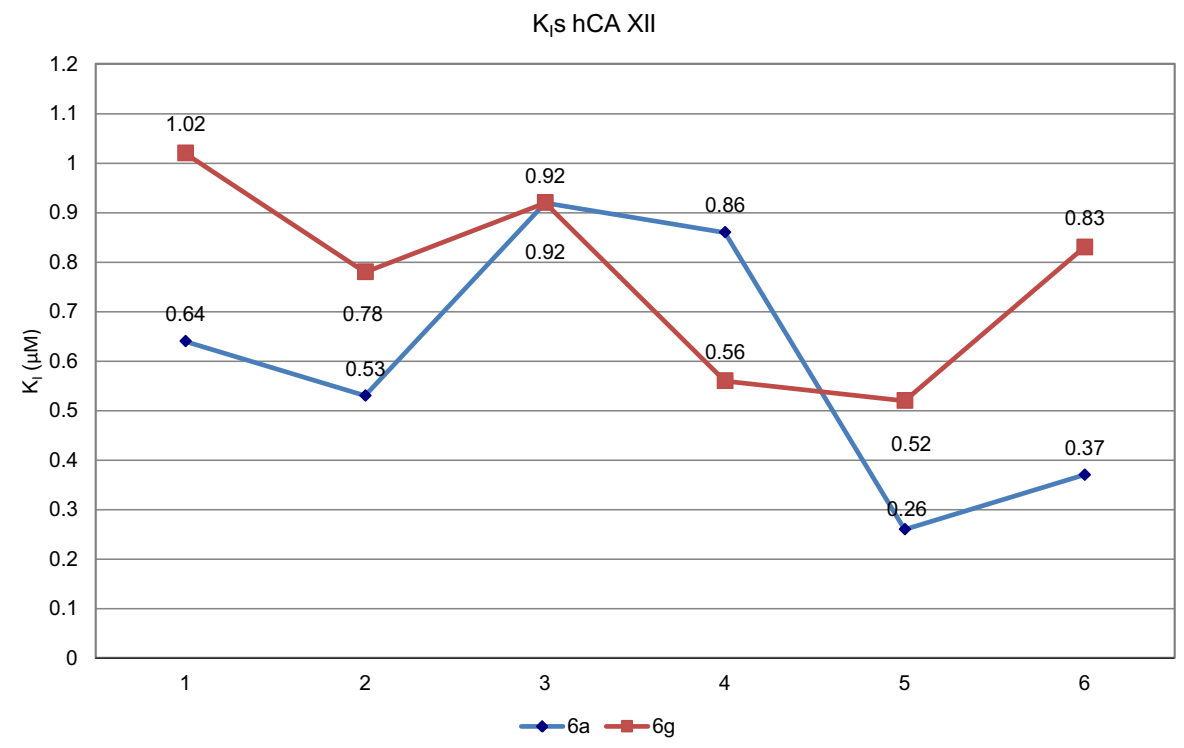

Chart 5. Change in the $K_{\mathrm{I}}$ values for $\mathbf{6 a}-\mathbf{f}$ (red line) and $\mathbf{6 g - 1}$ (blue line). 
6g-1 are -meta) also influence the $K_{\mathrm{I}}$ values. However, a salient feature of all these sulfonamides is their rather flat SAR, probably due to the extreme bulkiness of the tails that they incorporate and which probably extend out of the active site.

For the dominant cytosolic isoform hCA II, as for isoform CA I, it was observed that the new derivatives were rather ineffective inhibitors, showing a limited range of inhibitory power, with a variation of $K_{\mathrm{I}}$ between 0.10 and $0.96 \mu \mathrm{M}$. However, the $K_{\mathrm{I}}$ values were slightly lower for on hCA II when compared with other CA isoforms and any important effect of bulkiness of tail was not observed for this isoform (Chart 3). It is suggested that due to the fact hCA II has a wide entrance to active site, probably the hydrophobic and hydrophilic interactions of these tails with the active site were not highly effective, and leading in fact to the flat SAR mentioned above also for isoform hCA I.

The transmembrane isoform hCA IX was inhibited better than the cytosolic ones, with $K_{\mathrm{I}} \mathrm{S}$ ranging between $90 \mathrm{nM}$ and $1.12 \mu \mathrm{M}$ (Table 1). However the isoform which was better inhibited was hCA XII (a transmembrane one as hCA IX), with $K_{\mathrm{I}}$ s ranging between $30 \mathrm{nM}$ and $1.02 \mu \mathrm{M}$. The small range of inhibitory power of these compounds against the two transmembrane isoforms may be due to the fact that the variations in the structure are at rather distant parts of the tail from the primary sulfonamide, and we hypothesize that these parts of the molecules lay outside the active site, affording thus for less specific interactions with amino acid residues crucial for the binding of inhibitors. It is thus probable that the bulky scaffold of these sulfonamides does not make a lot of favorable contacts with the enzyme active site, whereas the secondary sulfonamide moiety is too far away for assuring the right interactions with the residues at the entrance of the cavity, which would lead to isoform-selective CAIs (Charts 4 and 5). ${ }^{13-15}$

\section{Conclusion}

There are still many important drug design aspect to be addressed for obtaining isoform-selective and more effective sulfonamide CAIs. Considering our interest in sulfonamides, herein we investigate a new series of acridine bis-sulfonamides which have been obtained by using multicomponent reaction techniques. The new series of acridine bis-sulfonamides was synthesized with effective yields. The compounds were characterized by physicochemical methods and tested for their in vitro inhibition activity against the CA isoforms I, II, IX and XII. Several compounds showed low micromolar inhibition against the pharmacologically relevant isoforms hCA I, II, IX, and XII. The prepared compounds containing both acridine ring and sulfonamide group are thought to be of interest because sulfonamides are used in the treatment of many diseases, possessing antimicrobial, antimalarial, antiglaucoma, and anticancer properties.

\section{Experimental}

\subsection{Chemistry}

The chemicals used in the synthesis of acridine bis-sulfonamide derivatives were obtained from Merck and Aldrich Chemical Company. All chemicals and solvents used for the synthesis were of spectroscopic reagent grade.

Melting points were measured on a Bibby Scientific Stuart Digital, Advanced, and SMP30. Fourier Transform Infrared (FT-IR) spectra were recorded on Bruker Optics, ALPHA FT-IR spectrometer. The ${ }^{1} \mathrm{H}$ NMR and ${ }^{13} \mathrm{C}$ NMR spectra were obtained in DMSO- $d_{6}$ with Bruker DPX-300 as solvents with tetramethylsilane as the internal reference. The mass analyses were performed on an Agilent Technologies 6530 Accurate-Mass Q-TOF LC/HRMS at the advanced technology research center of Dumlupınar University (ILTEM).

\subsection{General procedure for preparation of nitro-acridine sulfonamide compounds $(4 a, 4 b)$}

A mixture of a dimedone $\mathbf{1}(0.280 \mathrm{~g}, 2 \mathrm{mmol})$, 4-aminobenzenesulfonamide $(0.172 \mathrm{~g}, 1 \mathrm{mmol}) 2$, -meta and -para substitute nitrobenzaldehydes (3a and 3b) (0.106 g, $1 \mathrm{mmol})$, and $p$-dodecylbenzenesulfonic acid (DBSA) $(0.033 \mathrm{~g}, 10 \mathrm{mmol} \%)$ in $40 \mathrm{~mL} \mathrm{H}_{2} \mathrm{O}$ was stirred and refluxing for $24 \mathrm{~h}$. The progress of the reaction was monitored by TLC. After, the reaction is completed, the mixture was cooled to room temperature solid filtered off and washed with $\mathrm{H}_{2} \mathrm{O}$. The products ( $\mathbf{4 a}$ and $\mathbf{4 b}$ ) were purified and recrystallized from ethanol. ${ }^{10}$

4.2.1. 4-(3,3,6,6-Tetramethyl-9-(4-nitrophenyl)-1,8-dioxo-1,2,3, 4,5,6,7,8-octahydroacridin-10 $(9 H)$-yl)benzenesulfonamide (4a) As yellow solid (ethanol), mp $298-300{ }^{\circ} \mathrm{C}$ (Lit. >250), ${ }^{30}$ yield $93 \%$.

4.2.2. 4-(3,3,6,6-Tetramethyl-9-(3-nitrophenyl)-1,8-dioxo-1,2,3, 4,5,6,7,8-octahydroacridin-10 $(9 \mathrm{H})$-yl)benzenesulfonamide (4b) $89 \%$.

As yellow solid (ethanol), mp $256-257^{\circ} \mathrm{C}$ (Lit. $\left.>250\right)^{30}$ yield

\subsection{General procedure for preparation of amino-acridine sulfonamide compounds $(5 a, 5 b)$}

$\mathrm{Na}_{2} \mathrm{~S} \cdot 9 \mathrm{H}_{2} \mathrm{O}(1 \mathrm{mmol})$ and sulfur $(2 \mathrm{mmol})$ were dissolved by boiling in $20 \mathrm{ml}$ of water. This solution (sodium poly-sulfur) was then added dropwise to a stirred solution of warm nitro acridine compounds (4a, $\mathbf{4 b})(1 \mathrm{mmol})$ in ethanol-water. The progress of the reaction was monitored by TLC. Once the reaction is completed, the mixture was cooled to room temperature and solid filtered off and washed with $\mathrm{H}_{2} \mathrm{O}{ }^{10}$

4.3.1. 4-(9-(4-Aminophenyl)-3,3,6,6-tetramethyl-1,8-dioxo-1,2, 3,4,5,6,7,8-octahydroacridin-10(9H)-yl)benzenesulfonamide (5a)

As white solid (ethanol), mp $257-258{ }^{\circ} \mathrm{C}$, yield $87 \%$. IR $\left(\mathrm{cm}^{-1}\right)$ : 3458 and $3371 \mathrm{w}\left(-\mathrm{NH}_{2}\right), 3040 \mathrm{w}(\mathrm{Ar}-\mathrm{H}), 2954 \mathrm{w}(\mathrm{C}-\mathrm{H}), 1626 \mathrm{~s}$ $(\mathrm{C}=\mathrm{O}), 1577 \mathrm{~s}(\mathrm{C}=\mathrm{C}), 1363$ and $1152 \mathrm{~s}\left(\mathrm{SO}_{2}\right) ;{ }^{1} \mathrm{H}$ NMR $(300 \mathrm{MHz}$, DMSO- $\left.d_{6}\right) \delta(\mathrm{ppm}): 0.70\left(\mathrm{~s}, 6 \mathrm{H}, 2 \times-\mathrm{CH}_{3}\right), 0.90\left(\mathrm{~s}, 6 \mathrm{H}, 2 \times-\mathrm{CH}_{3}\right)$, $1.71\left(\mathrm{~d}, 2 \mathrm{H}, J=17.2 \mathrm{~Hz},-\mathrm{CH}_{2}\right), 2.00\left(\mathrm{~d}, 2 \mathrm{H}, J=16.1 \mathrm{~Hz},-\mathrm{CH}_{2}\right.$ ), $2.18\left(\mathrm{~d}, 4 \mathrm{H}, J=16.5 \mathrm{~Hz}, 2 \times-\mathrm{CH}_{2}\right), 4.80\left(\mathrm{~s}, 2 \mathrm{H},-\mathrm{NH}_{2}\right), 4.90(\mathrm{~s}$, $1 \mathrm{H},-\mathrm{CH}), 6.43(\mathrm{~d}, 2 \mathrm{H}, J=8.4 \mathrm{~Hz}, \mathrm{Ar}-\mathrm{H}), 6.95(\mathrm{~d}, 2 \mathrm{H}, J=8.4 \mathrm{~Hz}$, $\mathrm{Ar}-\mathrm{H}), 7.62-7.68\left(\mathrm{~m}, 4 \mathrm{H}, \mathrm{Ar}-\mathrm{H}\right.$ and $\left.-\mathrm{SO}_{2} \mathrm{NH}_{2}\right), 8.03(\mathrm{~d}, 2 \mathrm{H}$, $J=8.7 \mathrm{~Hz}, \mathrm{Ar}-\mathrm{H}) ;{ }^{13} \mathrm{C}$ NMR $\left(75 \mathrm{MHz}, \mathrm{DMSO}-d_{6}\right) \delta(\mathrm{ppm}): 26.53$, 29.79, 30.92, 32.44, 41.33, 50.17, 114.07, 114.23, 122.88, 128.35, $132.46,133.49,134.46,138.42,146.87,149.81,195.57$; HRMS (QTOF-ESI): $\mathrm{m} / \mathrm{z}$ calcd for $\mathrm{C}_{29} \mathrm{H}_{33} \mathrm{~N}_{3} \mathrm{O}_{4} \mathrm{~S}$ : 519.2192; found: $518.2321[\mathrm{M}-\mathrm{H}]^{-}$.

4.3.2. 4-(9-(3-Aminophenyl)-3,3,6,6-tetramethyl-1,8-dioxo-1,2, 3,4,5,6,7,8-octahydroacridin-10(9H)-yl)benzenesulfonamide (5b)

As white solid (ethanol), $\mathrm{mp} 218-219{ }^{\circ} \mathrm{C}$, yield $82 \%$. IR $\left(\mathrm{cm}^{-1}\right)$ : 3368 and $3272 \mathrm{w}\left(-\mathrm{NH}_{2}\right), 3066 \mathrm{w}(\mathrm{Ar}-\mathrm{H}), 2957 \mathrm{w}(\mathrm{C}-\mathrm{H}), 1628 \mathrm{~s}$ $(\mathrm{C}=\mathrm{O}), 1574 \mathrm{~s}(\mathrm{C}=\mathrm{C}), 1334$ and $1155 \mathrm{~s}\left(\mathrm{SO}_{2}\right) ;{ }^{1} \mathrm{H} \mathrm{NMR}(300 \mathrm{MHz}$, DMSO- $\left.d_{6}\right) \delta(\mathrm{ppm}): 0.70\left(\mathrm{~s}, 6 \mathrm{H}, 2 \times-\mathrm{CH}_{3}\right), 0.90\left(\mathrm{~s}, 6 \mathrm{H}, 2 \times-\mathrm{CH}_{3}\right)$, $1.72\left(\mathrm{~d}, 2 \mathrm{H}, J=17.2 \mathrm{~Hz},-\mathrm{CH}_{2}\right), 2.02\left(\mathrm{~d}, 2 \mathrm{H}, J=16.0 \mathrm{~Hz},-\mathrm{CH}_{2}\right.$ ), 2.16-2.22 (m, 4H, $\left.2 \times-\mathrm{CH}_{2}\right), 4.90(\mathrm{~s}, 1 \mathrm{H},-\mathrm{CH}), 5.10(\mathrm{~s}, 2 \mathrm{H}$, $\left.-\mathrm{NH}_{2}\right), 6.30-6.33(\mathrm{~m}, 1 \mathrm{H}, \mathrm{Ar}-\mathrm{H}), 6.50(\mathrm{~d}, 2 \mathrm{H}, J=7.7 \mathrm{~Hz}, \mathrm{Ar}-\mathrm{H})$, $6.89(\mathrm{t}, J=7.7 \mathrm{~Hz}, 1 \mathrm{H}, \mathrm{Ar}-\mathrm{H}), 7.61\left(\mathrm{~s}, 2 \mathrm{H},-\mathrm{SO}_{2} \mathrm{NH}_{2}\right), 7.64(\mathrm{~d}, 2 \mathrm{H}$, $J=8.7 \mathrm{~Hz}, \quad \mathrm{Ar}-\mathrm{H}), 8.03(\mathrm{~d}, 2 \mathrm{H}, J=8.7 \mathrm{~Hz}, \mathrm{Ar}-\mathrm{H}) ;{ }^{13} \mathrm{C}$ NMR $\left(75 \mathrm{MHz}, \mathrm{DMSO}-d_{6}\right) \delta(\mathrm{ppm}): 26.56,29.56,32.59,32.97,41.41$, $49.80,112.84,121.53,122.67,127.92,130.23,131.04,134.73$, 
141.34, 145.34, 147.88, 148.51, 150.99, 195.63; HRMS (QTOF-ESI): $\mathrm{m} / z$ calcd for $\mathrm{C}_{29} \mathrm{H}_{33} \mathrm{~N}_{3} \mathrm{O}_{4} \mathrm{~S}$ : 519.2192; found: $518.2271[\mathrm{M}-\mathrm{H}]^{-}$.

\subsection{General procedure for preparation of acridine bis-} sulfonamide derivatives $(6 a-1)$

4-Amino-acridine sulfonamide 5a $(0.520 \mathrm{~g}, 1 \mathrm{mmol})$, benzene sulfonyl chloride $(0.177 \mathrm{~g}, 1 \mathrm{mmol})$, and $0.5 \mathrm{~mL}$ dry triethylamine (TEA) were stirred in dry $5 \mathrm{~mL}$ THF for $5 \mathrm{~h}$ at room temperature. After the solvent was removed under in vacuo and washed with $\mathrm{H}_{2} \mathrm{O} .{ }^{31}$

4.4.1. $N$-(4-(3,3,6,6-Tetramethyl-1,8-dioxo-10-(4-sulfamoylphenyl)-1,2,3,4,5,6,7,8,9,10-decahydro acridin-9-yl)phenyl)benzenesulfonamide (6a)

As white solid (ethanol), mp $208-210{ }^{\circ} \mathrm{C}$, yield $90 \%$. IR $\left(\mathrm{cm}^{-1}\right)$ : $3375 \mathrm{w}\left(-\mathrm{NH}_{2}\right), 3075 \mathrm{w}(\mathrm{Ar}-\mathrm{H}), 2959 \mathrm{w}(\mathrm{C}-\mathrm{H}), 1623 \mathrm{~s}(\mathrm{C}=\mathrm{O})$, $1589 \mathrm{~s}(\mathrm{C}=\mathrm{C}), 1362$ and $1153 \mathrm{~s}\left(\mathrm{SO}_{2}\right) ;{ }^{1} \mathrm{H}$ NMR (300 MHz, DMSO$\left.d_{6}\right) \delta(\mathrm{ppm}): 0.70\left(\mathrm{~s}, 6 \mathrm{H}, 2 \times-\mathrm{CH}_{3}\right), 0.90\left(\mathrm{~s}, 6 \mathrm{H}, 2 \times-\mathrm{CH}_{3}\right), 1.70$ (d, $\left.2 \mathrm{H}, J=17.2 \mathrm{~Hz},-\mathrm{CH}_{2}\right), 1.98\left(\mathrm{~d}, 2 \mathrm{H}, J=16.0 \mathrm{~Hz},-\mathrm{CH}_{2}\right), 2.16$ (d, $\left.4 \mathrm{H}, J=16.5 \mathrm{~Hz}, 2 \times-\mathrm{CH}_{2}\right), 4.93(\mathrm{~s}, 1 \mathrm{H},-\mathrm{CH}), 6.95(\mathrm{~d}, 2 \mathrm{H}$, $J=8.5 \mathrm{~Hz}, \mathrm{Ar}-\mathrm{H}), 7.15(\mathrm{~d}, 2 \mathrm{H}, J=8.5 \mathrm{~Hz}, \mathrm{Ar}-\mathrm{H}), 7.46-7.70(\mathrm{~m}, 7 \mathrm{H}$, $\mathrm{Ar}-\mathrm{H}), 7.61\left(\mathrm{~s}, 2 \mathrm{H},-\mathrm{SO}_{2} \mathrm{NH}_{2}\right), 8.01(\mathrm{~d}, 2 \mathrm{H}, J=8.6 \mathrm{~Hz}, \mathrm{Ar}-\mathrm{H})$, $10.10(\mathrm{~s}, 1 \mathrm{H},-\mathrm{NH}) ;{ }^{13} \mathrm{C}$ NMR $\left(75 \mathrm{MHz}\right.$, DMSO-d $\left.d_{6}\right) \delta(\mathrm{ppm}): 26.46$, $29.65,31.72$, 32.50, 41.41, 49.95, 113.49, 120.60, 126.96, 127.80, $128.62,129.55,131.13,133.21,135.74,140.14,141.57,142.56$, $145.15,150.08,195.50$; HRMS (QTOF-ESI): $m / z$ calcd for $\mathrm{C}_{35} \mathrm{H}_{37} \mathrm{~N}_{3}-$ $\mathrm{O}_{6} \mathrm{~S}_{2}$ : 659.2124; found: $682.2021[\mathrm{M}+\mathrm{Na}]^{+}$.

4.4.2. 4-Methyl- $N$-(4-(3,3,6,6-tetramethyl-1,8-dioxo-10-(4-sulfamoylphenyl)-1,2,3,4,5,6,7,8,9,10-decahydroacridin-9-yl)phenyl) benzenesulfonamide ( $6 \mathrm{~b}$ )

As white solid (ethanol), mp 230-231 ${ }^{\circ} \mathrm{C}$, yield $92 \%$. IR $\left(\mathrm{cm}^{-1}\right)$ : $3357 \mathrm{w}\left(-\mathrm{NH}_{2}\right), 3033 \mathrm{w}(\mathrm{Ar}-\mathrm{H}), 2959 \mathrm{w}(\mathrm{C}-\mathrm{H}), 1631 \mathrm{~s}(\mathrm{C}=\mathrm{O})$, $1590 \mathrm{~s}(\mathrm{C}=\mathrm{C}), 1365$ and $1159 \mathrm{~s}\left(\mathrm{SO}_{2}\right) ;{ }^{1} \mathrm{H}$ NMR (300 MHz, DMSO$\left.d_{6}\right) \delta(\mathrm{ppm}): 0.70\left(\mathrm{~s}, 6 \mathrm{H}, 2 \times-\mathrm{CH}_{3}\right), 0.90\left(\mathrm{~s}, 6 \mathrm{H}, 2 \times-\mathrm{CH}_{3}\right), 1.70$ $\left(\mathrm{d}, 2 \mathrm{H}, J=17.3 \mathrm{~Hz},-\mathrm{CH}_{2}\right), 1.98\left(\mathrm{~d}, 2 \mathrm{H}, J=16.0 \mathrm{~Hz},-\mathrm{CH}_{2}\right), 2.16$ (d, $\left.4 \mathrm{H}, J=16.5 \mathrm{~Hz}, 2 \times-\mathrm{CH}_{2}\right), 2.31\left(\mathrm{~s}, 3 \mathrm{H},-\mathrm{CH}_{3}\right), 4.92(\mathrm{~s}, 1 \mathrm{H},-\mathrm{CH})$, $6.95(\mathrm{~d}, 2 \mathrm{H}, J=8.5 \mathrm{~Hz}, \mathrm{Ar}-\mathrm{H}), 7.15(\mathrm{~d}, 2 \mathrm{H}, J=8.5 \mathrm{~Hz}, \mathrm{Ar}-\mathrm{H}), 7.28$ $(\mathrm{d}, 2 \mathrm{H}, J=8.1 \mathrm{~Hz}, \mathrm{Ar}-\mathrm{H}), 7.58(\mathrm{~d}, 2 \mathrm{H}, J=8.3 \mathrm{~Hz}, \mathrm{Ar}-\mathrm{H}), 7.61$ (s, $\left.2 \mathrm{H},-\mathrm{SO}_{2} \mathrm{NH}_{2}\right), 7.66(\mathrm{~d}, 2 \mathrm{H}, J=8.5 \mathrm{~Hz}, \mathrm{Ar}-\mathrm{H}), 8.01(\mathrm{~d}, 2 \mathrm{H}$, $J=8.5 \mathrm{~Hz}, \mathrm{Ar}-\mathrm{H}), 10.05(\mathrm{~s}, 1 \mathrm{H},-\mathrm{NH}) ;{ }^{13} \mathrm{C}$ NMR $(75 \mathrm{MHz}$, DMSO$\left.d_{6}\right) \delta(\mathrm{ppm}): 21.41,26.46,29.65,31.72,32.51,41.41,49.95$, $113.51,120.34,127.03,127.81,128.61,130.01,131.14,135.89$, 137.35, 141.58, 142.38, 143.53, 145.15, 150.08, 195.52; HRMS (QTOF-ESI): $\mathrm{m} / \mathrm{z}$ calcd for $\mathrm{C}_{36} \mathrm{H}_{39} \mathrm{~N}_{3} \mathrm{O}_{6} \mathrm{~S}_{2}:$ 673.2280; found: $696.2194[\mathrm{M}+\mathrm{Na}]^{+}$.

4.4.3. 4-Methoxy- $N$-(4-(3,3,6,6-tetramethyl-1,8-dioxo-10-(4-sulfamoylphenyl)-1,2,3,4,5,6,7,8,9,10-decahydroacridin-9-yl)phenyl) benzenesulfonamide (6c)

As white solid (ethanol), mp 215-216 ${ }^{\circ} \mathrm{C}$, yield $94 \%$. IR $\left(\mathrm{cm}^{-1}\right)$ : $3393 \mathrm{w}\left(-\mathrm{NH}_{2}\right), 3064 \mathrm{w}(\mathrm{Ar}-\mathrm{H}), 2958 \mathrm{w}(\mathrm{C}-\mathrm{H}), 1626 \mathrm{~s}(\mathrm{C}=\mathrm{O})$, $1584 \mathrm{~s}(\mathrm{C}=\mathrm{C}), 1361$ and $1151 \mathrm{~s}\left(\mathrm{SO}_{2}\right) ;{ }^{1} \mathrm{H}$ NMR (300 MHz, DMSO$\left.d_{6}\right) \delta(\mathrm{ppm}): 0.65\left(\mathrm{~s}, 6 \mathrm{H}, 2 \times-\mathrm{CH}_{3}\right), 0.85\left(\mathrm{~s}, 6 \mathrm{H}, 2 \times-\mathrm{CH}_{3}\right), 1.70$ $\left(\mathrm{d}, 2 \mathrm{H}, J=17.2 \mathrm{~Hz},-\mathrm{CH}_{2}\right), 1.99\left(\mathrm{~d}, 2 \mathrm{H}, \mathrm{J}=16.0 \mathrm{~Hz},-\mathrm{CH}_{2}\right), 2.17$ (d, $\left.4 \mathrm{H}, J=16.5 \mathrm{~Hz}, 2 \times-\mathrm{CH}_{2}\right), 3.80\left(\mathrm{~s}, 3 \mathrm{H},-\mathrm{OCH}_{3}\right), 4.93(\mathrm{~s}, 1 \mathrm{H},-\mathrm{CH})$, $6.95(\mathrm{~d}, 2 \mathrm{H}, J=8.5 \mathrm{~Hz}, \mathrm{Ar}-\mathrm{H}), 6.99(\mathrm{~d}, 2 \mathrm{H}, J=8.9 \mathrm{~Hz}, \mathrm{Ar}-\mathrm{H}), 7.15$ $(\mathrm{d}, 2 \mathrm{H}, J=8.5 \mathrm{~Hz}, \mathrm{Ar}-\mathrm{H}), 7.61\left(\mathrm{~s}, 2 \mathrm{H},-\mathrm{SO}_{2} \mathrm{NH}_{2}\right), 7.63-7.66(\mathrm{~m}$, $4 \mathrm{H}, \mathrm{Ar}-\mathrm{H}), 8.02(\mathrm{~d}, 2 \mathrm{H}, J=8.5 \mathrm{~Hz}, \mathrm{Ar}-\mathrm{H}), 9.98(\mathrm{~s}, 1 \mathrm{H},-\mathrm{NH}) ;{ }^{13} \mathrm{C}$ NMR (75 MHz, DMSO- $\left.d_{6}\right) \delta(\mathrm{ppm}): 26.46,29.65,31.69,32.50$, $41.41,49.95,56.00,113.51,114.68,120.28,127.80,128.58$, $129.20,131.12,131.80,136.01,141.58,142.28,145.15,150.07$, $162.75,195.51$; HRMS (QTOF-ESI): $\mathrm{m} / z$ calcd for $\mathrm{C}_{36} \mathrm{H}_{39} \mathrm{~N}_{3} \mathrm{O}_{7} \mathrm{~S}_{2}$ : 689.2229; found: $712.2138[\mathrm{M}+\mathrm{Na}]^{+}$.
4.4.4. 4-Bromo- $N$-(4-(3,3,6,6-tetramethyl-1,8-dioxo-10-(4-sulfamoylphenyl)-1,2,3,4,5,6,7,8,9,10-decahydroacridin-9-yl)phenyl) benzenesulfonamide( $6 \mathrm{~d})$

As white solid (ethanol), mp $235-236{ }^{\circ} \mathrm{C}$, yield $97 \%$. IR $\left(\mathrm{cm}^{-1}\right)$ : $3377 \mathrm{w}\left(-\mathrm{NH}_{2}\right), 3095 \mathrm{w}(\mathrm{Ar}-\mathrm{H}), 2957 \mathrm{w}(\mathrm{C}-\mathrm{H}), 1627 \mathrm{~s}(\mathrm{C}=\mathrm{O})$ $1579 \mathrm{~s}(\mathrm{C}=\mathrm{C}), 1363$ and $1159 \mathrm{~s}\left(\mathrm{SO}_{2}\right) ;{ }^{1} \mathrm{H}$ NMR (300 MHz, DMSO$\left.d_{6}\right) \delta(\mathrm{ppm}): 0.70\left(\mathrm{~s}, 6 \mathrm{H}, 2 \times-\mathrm{CH}_{3}\right), 0.90\left(\mathrm{~s}, 6 \mathrm{H}, 2 \times-\mathrm{CH}_{3}\right), 1.70$ $\left(\mathrm{d}, 2 \mathrm{H}, J=17.2 \mathrm{~Hz},-\mathrm{CH}_{2}\right), 1.99\left(\mathrm{~d}, 2 \mathrm{H}, J=15.9 \mathrm{~Hz},-\mathrm{CH}_{2}\right), 2.17(\mathrm{~d}$ $\left.4 \mathrm{H}, J=16.5 \mathrm{~Hz}, 2 \times-\mathrm{CH}_{2}\right), 4.92(\mathrm{~s}, 1 \mathrm{H},-\mathrm{CH}), 6.95(\mathrm{~d}, 2 \mathrm{H}$ $J=8.5 \mathrm{~Hz}, \mathrm{Ar}-\mathrm{H}), 7.17(\mathrm{~d}, 2 \mathrm{H}, J=8.5 \mathrm{~Hz}, \mathrm{Ar}-\mathrm{H}), 7.61\left(\mathrm{~s}, 2 \mathrm{H},-\mathrm{SO}_{2}-\right.$ $\left.\mathrm{NH}_{2}\right), 7.58-7.71(\mathrm{~m}, 6 \mathrm{H}, \mathrm{Ar}-\mathrm{H}), 8.02(\mathrm{~d}, 2 \mathrm{H}, J=8.5 \mathrm{~Hz}, \mathrm{Ar}-\mathrm{H}), 10.20$ $(\mathrm{s}, 1 \mathrm{H},-\mathrm{NH}) ;{ }^{13} \mathrm{C}$ NMR $\left(75 \mathrm{MHz}\right.$, DMSO-d $\left.{ }_{6}\right) \delta$ (ppm): 26.42, 29.67, $31.78,32.50,41.41,49.94,113.45,120.85,127.10,127.82,128.73$, 129.03, 131.14, 132.67, 135.40, 139.30, 141.57, 142.87, 145.15, 150.10, 195.50; HRMS (QTOF-ESI): $m / z$ calcd for $\mathrm{C}_{35} \mathrm{H}_{36} \mathrm{BrN}_{3} \mathrm{O}_{6} \mathrm{~S}_{2}$ : 737.1229; found: $760.1125[\mathrm{M}+\mathrm{Na}]^{+}$.

4.4.5. 2,4,6-Trimethyl- $N$-(4-(3,3,6,6-tetramethyl-1,8-dioxo-10(4-sulfamoylphenyl)-1,2,3,4,5,6,7,8,9,10-decahydroacridin-9-yl) phenyl)benzenesulfonamide (6e)

As white solid (ethanol), mp 239-240 ${ }^{\circ} \mathrm{C}$, yield $93 \%$. IR $\left(\mathrm{cm}^{-1}\right)$ : 3467 and $3388 \mathrm{w}\left(-\mathrm{NH}_{2}\right), 3172 \mathrm{w}(-\mathrm{NH}), 3035 \mathrm{w}(\mathrm{Ar}-\mathrm{H}), 2958$ w $(\mathrm{C}-\mathrm{H}), 1623 \mathrm{~s}(\mathrm{C}=\mathrm{O}), 1582 \mathrm{~s}(\mathrm{C}=\mathrm{C}), 1360$ and $1146 \mathrm{~s}\left(\mathrm{SO}_{2}\right) ;{ }^{1} \mathrm{H}$ NMR $\left(300 \mathrm{MHz}\right.$, DMSO- $\left.d_{6}\right) \delta(\mathrm{ppm}): 0.70\left(\mathrm{~s}, 6 \mathrm{H}, 2 \times-\mathrm{CH}_{3}\right), 0.90$ $\left(\mathrm{s}, 6 \mathrm{H}, 2 \times-\mathrm{CH}_{3}\right), 1.70\left(\mathrm{~d}, 2 \mathrm{H}, J=17.2 \mathrm{~Hz},-\mathrm{CH}_{2}\right), 1.98(\mathrm{~d}, 2 \mathrm{H}$, $\left.J=15.9 \mathrm{~Hz},-\mathrm{CH}_{2}\right), 2.16\left(\mathrm{~d}, 4 \mathrm{H}, J=16.6 \mathrm{~Hz}, 2 \times-\mathrm{CH}_{2}\right), 2.21(\mathrm{~s}, 3 \mathrm{H}$, $\left.-\mathrm{CH}_{3}\right), 2.47\left(\mathrm{~s}, 6 \mathrm{H}, 2 \times-\mathrm{CH}_{3}\right), 4.90(\mathrm{~s}, 1 \mathrm{H},-\mathrm{CH}), 6.85(\mathrm{~d}, 2 \mathrm{H}$ $J=8.5 \mathrm{~Hz}, \mathrm{Ar}-\mathrm{H}), 6.95(\mathrm{~s}, 2 \mathrm{H}, \mathrm{Ar}-\mathrm{H}), 7.14(\mathrm{~d}, 2 \mathrm{H}, J=8.5 \mathrm{~Hz}, \mathrm{Ar}-\mathrm{H})$, $7.61\left(\mathrm{~s}, 2 \mathrm{H},-\mathrm{SO}_{2} \mathrm{NH}_{2}\right), 7.64(\mathrm{~d}, 2 \mathrm{H}, J=8.6 \mathrm{~Hz}, \mathrm{Ar}-\mathrm{H}), 8.01$ (d, $2 \mathrm{H}$, $J=8.6 \mathrm{~Hz}, \mathrm{Ar}-\mathrm{H}), 9.90(\mathrm{~s}, 1 \mathrm{H},-\mathrm{NH}) ;{ }^{13} \mathrm{C}$ NMR $(75 \mathrm{MHz}$, DMSO$\left.d_{6}\right) \delta(\mathrm{ppm}): 20.84,22.91,26.50,29.64,31.79,32.50,41.40,49.95$ $113.52,120.65,127.79,128.62,131.11,132.16,134.58,135.50$, $139.00,141.59,142.27,142.44,145.15,150.07,195.50$; HRMS (QTOF-ESI): $\mathrm{m} / \mathrm{z}$ calcd for $\mathrm{C}_{38} \mathrm{H}_{43} \mathrm{~N}_{3} \mathrm{O}_{6} \mathrm{~S}_{2}$ : 701.2593; found: $724.2482[\mathrm{M}+\mathrm{Na}]^{+}$.

4.4.6. $N$-(4-(3,3,6,6-Tetramethyl-1,8-dioxo-10-(4-sulfamoylphenyl)-1,2,3,4,5,6,7,8,9,10-decahydroacridin-9-yl)phenyl)naphthalene-2-sulfonamide (6f)

As white solid (ethanol), mp $243-245^{\circ} \mathrm{C}$, yield $95 \%$. IR $\left(\mathrm{cm}^{-1}\right)$ : $3382 \mathrm{w}\left(-\mathrm{NH}_{2}\right), 3249 \mathrm{w}(-\mathrm{NH}), 3032 \mathrm{w}(\mathrm{Ar}-\mathrm{H}), 2957 \mathrm{w}(\mathrm{C}-\mathrm{H})$ $1625 \mathrm{~s}(\mathrm{C}=\mathrm{O}), 1582 \mathrm{~s}(\mathrm{C}=\mathrm{C}), 1363$ and $1153 \mathrm{~s}\left(\mathrm{SO}_{2}\right) ;{ }^{1} \mathrm{H}$ NMR $\left(300 \mathrm{MHz}, \mathrm{DMSO}-d_{6}\right) \delta(\mathrm{ppm}): 0.60\left(\mathrm{~s}, 6 \mathrm{H}, 2 \times-\mathrm{CH}_{3}\right), 0.80(\mathrm{~s}, 6 \mathrm{H}$ $\left.2 \times-\mathrm{CH}_{3}\right), 1.66\left(\mathrm{~d}, 2 \mathrm{H}, J=17.2 \mathrm{~Hz},-\mathrm{CH}_{2}\right), 1.93(\mathrm{~d}, 2 \mathrm{H}, J=15.9 \mathrm{~Hz}$ $-\mathrm{CH}_{2}$ ), 2.13 (d, $\left.4 \mathrm{H}, J=16.5 \mathrm{~Hz}, 2 \times-\mathrm{CH}_{2}\right), 4.90(\mathrm{~s}, 1 \mathrm{H},-\mathrm{CH}), 6.99$ (d, $2 \mathrm{H}, J=8.5 \mathrm{~Hz}, \mathrm{Ar}-\mathrm{H}$ ), $7.13(\mathrm{~d}, 2 \mathrm{H}, J=8.5 \mathrm{~Hz}, \mathrm{Ar}-\mathrm{H}), 7.61$ (s, $\left.2 \mathrm{H},-\mathrm{SO}_{2} \mathrm{NH}_{2}\right), 7.60-7.71(\mathrm{~m}, 5 \mathrm{H}, \mathrm{Ar}-\mathrm{H}), 7.97-8.08(\mathrm{~m}, 5 \mathrm{H}, \mathrm{Ar}-\mathrm{H})$ $8.36(\mathrm{~s}, 1 \mathrm{H}, \mathrm{Ar}-\mathrm{H}), 10.20(\mathrm{~s}, 1 \mathrm{H},-\mathrm{NH}) ;{ }^{13} \mathrm{C}$ NMR $(75 \mathrm{MHz}$, DMSO$\left.d_{6}\right) \delta(\mathrm{ppm}): 26.37,29.61,31.74,32.45,41.36,49.90,113.45$, $120.66,122.41,127.78,128.03,128.22,128.27,128.64,129.29$ 129.62, 129.73, 131.10, 131.96, 134.64, 135.71, 137.16, 141.55, 142.58, 145.13, 150.03, 195.45; HRMS (QTOF-ESI): $\mathrm{m} / \mathrm{z}$ calcd for $\mathrm{C}_{39} \mathrm{H}_{39} \mathrm{~N}_{3} \mathrm{O}_{6} \mathrm{~S}_{2}$ : 709.2280; found: $732.2168[\mathrm{M}+\mathrm{Na}]^{+}$.

4.4.7. $N$-(3-(3,3,6,6-Tetramethyl-1,8-dioxo-10-(4-sulfamoylphenyl)-1,2,3,4,5,6,7,8,9,10-decahydroacridin-9-yl)phenyl)benzenesulfonamide $(6 \mathrm{~g})$

As white solid (ethanol), mp $182-184^{\circ} \mathrm{C}$, yield $84 \%$. IR $\left(\mathrm{cm}^{-1}\right)$ : $3384 \mathrm{w}\left(-\mathrm{NH}_{2}\right), 3266 \mathrm{w}(-\mathrm{NH}), 3068 \mathrm{w}(\mathrm{Ar}-\mathrm{H}), 2956 \mathrm{w}(\mathrm{C}-\mathrm{H})$, $1633 \mathrm{~s}(\mathrm{C}=\mathrm{O}), 1584 \mathrm{~s}(\mathrm{C}=\mathrm{C}), 1364$ and $1161 \mathrm{~s}\left(\mathrm{SO}_{2}\right) ;{ }^{1} \mathrm{H} \mathrm{NMR}$ $\left(300 \mathrm{MHz}, \mathrm{DMSO}-d_{6}\right) \delta(\mathrm{ppm}): 0.70\left(\mathrm{~s}, 6 \mathrm{H}, 2 \times-\mathrm{CH}_{3}\right), 0.90(\mathrm{~s}, 6 \mathrm{H}$ $\left.2 \times-\mathrm{CH}_{3}\right), 1.68\left(\mathrm{~d}, 2 \mathrm{H}, J=17.3 \mathrm{~Hz},-\mathrm{CH}_{2}\right), 1.97(\mathrm{~d}, 2 \mathrm{H}, J=16.0 \mathrm{~Hz}$, $\left.-\mathrm{CH}_{2}\right), 2.15-2.22\left(\mathrm{~m}, 4 \mathrm{H}, 2 \times-\mathrm{CH}_{2}\right), 4.98(\mathrm{~s}, 1 \mathrm{H},-\mathrm{CH}), 6.81-6.83$ (m, 1H, Ar-H), 7.00-7.09 (m, 2H, Ar-H), $7.20(\mathrm{~s}, 1 \mathrm{H}, \mathrm{Ar}-\mathrm{H}), 7.61$ $\left(\mathrm{s}, 2 \mathrm{H},-\mathrm{SO}_{2} \mathrm{NH}_{2}\right), 7.43-7.72(\mathrm{~m}, 7 \mathrm{H}, \mathrm{Ar}-\mathrm{H}), 8.05(\mathrm{~d}, 2 \mathrm{H}$, $J=8.5 \mathrm{~Hz}, \mathrm{Ar}-\mathrm{H}), 10.20(\mathrm{~s}, 1 \mathrm{H},-\mathrm{NH}) ;{ }^{13} \mathrm{C} \mathrm{NMR}\left(75 \mathrm{MHz}, \mathrm{DMSO}-d_{6}\right)$ 
$\delta$ (ppm): 26.65, 29.67, 32.31, 32.44, 41.45, 49.96, 113.30, 118.27, $119.67,124.49,126.90,127.75,128.87,129.53,131.06,133.17$, $138.05,140.08,141.60,145.24,147.57,150.16,195.38$; HRMS (QTOF-ESI): $m / z$ calcd for $\mathrm{C}_{35} \mathrm{H}_{37} \mathrm{~N}_{3} \mathrm{O}_{6} \mathrm{~S}_{2}$ : 659.2124; found: $658.2239[\mathrm{M}-\mathrm{H}]^{-}$.

4.4.8. 4-Methyl- $N$-(3-(3,3,6,6-tetramethyl-1,8-dioxo-10-(4-sulfamoylphenyl)-1,2,3,4,5,6,7,8,9,10-decahydro acridin-9-yl)phenyl) benzenesulfonamide $(6 \mathrm{~h})$

As white solid (ethanol), mp $190-192{ }^{\circ} \mathrm{C}$, yield $86 \%$. IR $\left(\mathrm{cm}^{-1}\right)$ : $3396 \mathrm{w}\left(-\mathrm{NH}_{2}\right), 3252 \mathrm{w}(-\mathrm{NH}), 3098 \mathrm{w}(\mathrm{Ar}-\mathrm{H}), 2959 \mathrm{w}(\mathrm{C}-\mathrm{H})$, $1632 \mathrm{~s}(\mathrm{C}=\mathrm{O}), 1585 \mathrm{~s}(\mathrm{C}=\mathrm{C}), 1363$ and $1156 \mathrm{~s}\left(\mathrm{SO}_{2}\right) ;{ }^{1} \mathrm{H}$ NMR $\left(300 \mathrm{MHz}, \mathrm{DMSO}-d_{6}\right) \delta(\mathrm{ppm}): 0.70\left(\mathrm{~s}, 6 \mathrm{H}, 2 \times-\mathrm{CH}_{3}\right), 0.90(\mathrm{~s}, 6 \mathrm{H}$, $\left.2 \times-\mathrm{CH}_{3}\right), 1.68\left(\mathrm{~d}, 2 \mathrm{H}, J=17.4 \mathrm{~Hz},-\mathrm{CH}_{2}\right), 1.97(\mathrm{~d}, 2 \mathrm{H}, J=16.0 \mathrm{~Hz}$, $\left.-\mathrm{CH}_{2}\right), 2.15-2.22\left(\mathrm{~m}, 4 \mathrm{H}, 2 \times-\mathrm{CH}_{2}\right), 2.28\left(\mathrm{~s}, 3 \mathrm{H},-\mathrm{CH}_{3}\right), 4.98(\mathrm{~s}$, $1 \mathrm{H},-\mathrm{CH}), 6.81(\mathrm{~d}, 1 \mathrm{H}, J=7.6 \mathrm{~Hz}, \mathrm{Ar}-\mathrm{H}), 6.99-7.08(\mathrm{~m}, 2 \mathrm{H}, \mathrm{Ar}-\mathrm{H})$, $7.19(\mathrm{~s}, 1 \mathrm{H}, \mathrm{Ar}-\mathrm{H}), 7.25(\mathrm{~d}, 2 \mathrm{H}, J=8.1 \mathrm{~Hz}, \mathrm{Ar}-\mathrm{H}), 7.58(\mathrm{~d}, 2 \mathrm{H}$, $J=8.1 \mathrm{~Hz}, \mathrm{Ar}-\mathrm{H}), 7.62\left(\mathrm{~s}, 2 \mathrm{H},-\mathrm{SO}_{2} \mathrm{NH}_{2}\right), 7.66(\mathrm{~d}, 2 \mathrm{H}, J=8.5 \mathrm{~Hz}$, $\mathrm{Ar}-\mathrm{H}), 8.04(\mathrm{~d}, 2 \mathrm{H}, J=8.5 \mathrm{~Hz}, \mathrm{Ar}-\mathrm{H}), 10.10(\mathrm{~s}, 1 \mathrm{H},-\mathrm{NH}) ;{ }^{13} \mathrm{C}$ NMR $\left(75 \mathrm{MHz}\right.$, DMSO- $\left.d_{6}\right) \delta(\mathrm{ppm}): 22.85,26.60,29.69,32.29$, $32.43,41.46,49.96,113.32,118.12,119.56,124.37,126.96$, $127.75,128.84,129.98,131.10,137.27,138.19,141.60,143.42$, 145.24, 147.53, 150.16, 195.39; HRMS (QTOF-ESI): $\mathrm{m} / \mathrm{z}$ calcd for $\mathrm{C}_{36} \mathrm{H}_{39} \mathrm{~N}_{3} \mathrm{O}_{6} \mathrm{~S}_{2}$ : 673.2280; found: $672.2375[\mathrm{M}-\mathrm{H}]^{-}$.

4.4.9. 4-Methoxy- $N$-(3-(3,3,6,6-tetramethyl-1,8-dioxo-10-(4-sulfamoylphenyl)-1,2,3,4,5,6,7,8,9,10-decahydroacridin-9-yl)phenyl)benzenesulfonamide (6i)

As white solid (ethanol), mp 187-189 ${ }^{\circ} \mathrm{C}$, yield $87 \%$. IR $\left(\mathrm{cm}^{-1}\right)$ : $3386 \mathrm{w}\left(-\mathrm{NH}_{2}\right), 3247 \mathrm{w}(-\mathrm{NH}), 3088 \mathrm{w}(\mathrm{Ar}-\mathrm{H}), 2956 \mathrm{w}(\mathrm{C}-\mathrm{H})$, $1634 \mathrm{~s}(\mathrm{C}=\mathrm{O}), 1587 \mathrm{~s}(\mathrm{C}=\mathrm{C}), 1363$ and $1155 \mathrm{~s}\left(\mathrm{SO}_{2}\right) ;{ }^{1} \mathrm{H}$ NMR $\left(300 \mathrm{MHz}, \mathrm{DMSO}-d_{6}\right) \delta(\mathrm{ppm}): 0.65\left(\mathrm{~s}, 6 \mathrm{H}, 2 \times-\mathrm{CH}_{3}\right), 0.85(\mathrm{~s}, 6 \mathrm{H}$, $\left.2 \times-\mathrm{CH}_{3}\right), 1.68\left(\mathrm{~d}, 2 \mathrm{H}, J=17.2 \mathrm{~Hz},-\mathrm{CH}_{2}\right), 1.97(\mathrm{~d}, 2 \mathrm{H}, J=16.0 \mathrm{~Hz}$, $\left.-\mathrm{CH}_{2}\right), 2.18-2.22\left(\mathrm{~m}, 4 \mathrm{H}, 2 \times-\mathrm{CH}_{2}\right), 3.70\left(\mathrm{~s}, 3 \mathrm{H},-\mathrm{OCH}_{3}\right), 4.98(\mathrm{~s}$, $1 \mathrm{H},-\mathrm{CH}), 6.82-7.09(\mathrm{~m}, 5 \mathrm{H}, \mathrm{Ar}-\mathrm{H}), 7.16(\mathrm{~s}, 1 \mathrm{H}, \mathrm{Ar}-\mathrm{H}), 7.62-$ $7.68\left(\mathrm{~m}, 6 \mathrm{H}, \mathrm{Ar}-\mathrm{H}\right.$ and $\left.-\mathrm{SO}_{2} \mathrm{NH}_{2}\right), 8.05(\mathrm{~d}, 2 \mathrm{H}, J=8.5 \mathrm{~Hz}, \mathrm{Ar}-\mathrm{H})$, $10.00(\mathrm{~s}, 1 \mathrm{H},-\mathrm{NH}) ;{ }^{13} \mathrm{C}$ NMR (75 MHz, DMSO- $\left.d_{6}\right) \delta$ (ppm): 26.61, $29.66,32.28,32.44,41.45,49.97,55.98,113.32,114.65,118.21$, $119.66,124.33,127.74,128.81,129.13,131.11,131.74,138.26$, $141.59,145.24,147.51,150.14,162.67,195.38$; HRMS (QTOFESI): $m / z$ calcd for $\mathrm{C}_{36} \mathrm{H}_{39} \mathrm{~N}_{3} \mathrm{O}_{7} \mathrm{~S}_{2}$ : 689.2229; found: 688.2352 $[\mathrm{M}-\mathrm{H}]^{-}$.

4.4.10. 4-Bromo- $N$-(3-(3,3,6,6-tetramethyl-1,8-dioxo-10-(4-sulfamoylphenyl)-1,2,3,4,5,6,7,8,9,10-decahydro acridin-9-yl)phenyl)benzenesulfonamide $(\mathbf{6 j})$

As white solid (ethanol), mp 196-198 ${ }^{\circ} \mathrm{C}$, yield $94 \%$. IR $\left(\mathrm{cm}^{-1}\right)$ : $3383 \mathrm{w}\left(-\mathrm{NH}_{2}\right), 3248 \mathrm{w}(-\mathrm{NH}), 3078 \mathrm{w}(\mathrm{Ar}-\mathrm{H}), 2959 \mathrm{w}(\mathrm{C}-\mathrm{H})$, $1633 \mathrm{~s}(\mathrm{C}=\mathrm{O}), 1583 \mathrm{~s}(\mathrm{C}=\mathrm{C}), 1338$ and $1159 \mathrm{~s}\left(\mathrm{SO}_{2}\right) ;{ }^{1} \mathrm{H}$ NMR $\left(300 \mathrm{MHz}, \mathrm{DMSO}-d_{6}\right) \delta(\mathrm{ppm}): 0.65\left(\mathrm{~s}, 6 \mathrm{H}, 2 \times-\mathrm{CH}_{3}\right), 0.85(\mathrm{~s}, 6 \mathrm{H}$, $\left.2 \times-\mathrm{CH}_{3}\right), 1.67$ (d, $\left.2 \mathrm{H}, J=17.2 \mathrm{~Hz},-\mathrm{CH}_{2}\right), 1.97(\mathrm{~d}, 2 \mathrm{H}, J=15.9 \mathrm{~Hz}$, $\left.-\mathrm{CH}_{2}\right), 2.15-2.22\left(\mathrm{~m}, 4 \mathrm{H}, 2 \times-\mathrm{CH}_{2}\right), 4.95(\mathrm{~s}, 1 \mathrm{H},-\mathrm{CH}), 6.86(\mathrm{~d}$, $1 \mathrm{H}, J=7.9 \mathrm{~Hz}, \mathrm{Ar}-\mathrm{H}), 7.02-7.15(\mathrm{~m}, 3 \mathrm{H}, \mathrm{Ar}-\mathrm{H}), 7.62\left(\mathrm{~s}, 2 \mathrm{H},-\mathrm{SO}_{2^{-}}\right.$ $\left.\mathrm{NH}_{2}\right), 7.60-7.70(\mathrm{~m}, 6 \mathrm{H}, \mathrm{Ar}-\mathrm{H}), 8.05(\mathrm{~d}, 2 \mathrm{H}, J=8.5 \mathrm{~Hz}, \mathrm{Ar}-\mathrm{H}), 10.25$ $(\mathrm{s}, 1 \mathrm{H},-\mathrm{NH}) ;{ }^{13} \mathrm{C}$ NMR $\left(75 \mathrm{MHz}\right.$, DMSO-d $\left.d_{6}\right) \delta$ (ppm): 26.52, 29.69, 32.33, 32.43, 41.45, 49.93, 113.95, 118.67, 120.10, 124.59, 127.06, $127.78,128.99,129.05,131.04,132.65,137.62,139.17,141.55$, 145.24, 147.64, 149.80, 195.36; HRMS (QTOF-ESI): $\mathrm{m} / \mathrm{z}$ calcd for $\mathrm{C}_{35} \mathrm{H}_{36} \mathrm{BrN}_{3} \mathrm{O}_{6} \mathrm{~S}_{2}$ : 737.1229; found: $736.1343[\mathrm{M}-\mathrm{H}]^{-}$.

4.4.11. 2,4,6-Trimethyl- $N$-(3-(3,3,6,6-tetramethyl-1,8-dioxo-10(4-sulfamoylphenyl)-1,2,3,4,5,6,7,8,9,10-decahydroacridin-9-yl) phenyl)benzenesulfonamide (6k)

As white solid (ethanol), mp 203-204 ${ }^{\circ} \mathrm{C}$, yield $88 \%$. IR $\left(\mathrm{cm}^{-1}\right)$ : $3239 \mathrm{w}(-\mathrm{NH}), 3077 \mathrm{w}(\mathrm{Ar}-\mathrm{H}), 2957 \mathrm{w}(\mathrm{C}-\mathrm{H}), 1632 \mathrm{~s}(\mathrm{C}=\mathrm{O})$, $1584 \mathrm{~s}(\mathrm{C}=\mathrm{C}), 1333$ and $1151 \mathrm{~s}\left(\mathrm{SO}_{2}\right) ;{ }^{1} \mathrm{H}$ NMR $(300 \mathrm{MHz}$,
DMSO- $\left.d_{6}\right) \delta(\mathrm{ppm}): 0.70\left(\mathrm{~s}, 6 \mathrm{H}, 2 \times-\mathrm{CH}_{3}\right), 0.90\left(\mathrm{~s}, 6 \mathrm{H}, 2 \times-\mathrm{CH}_{3}\right)$, $1.68\left(\mathrm{~d}, 2 \mathrm{H}, J=17.4 \mathrm{~Hz},-\mathrm{CH}_{2}\right), 1.96\left(\mathrm{~d}, 2 \mathrm{H}, J=16.1 \mathrm{~Hz},-\mathrm{CH}_{2}\right)$, $2.18\left(\mathrm{~s}, 3 \mathrm{H},-\mathrm{CH}_{3}\right), 2.14-2.22\left(\mathrm{~m}, 4 \mathrm{H}, 2 \times-\mathrm{CH}_{2}\right), 2.52(\mathrm{~s}, 6 \mathrm{H}, 2 \times$ $\left.-\mathrm{CH}_{3}\right), 4.95(\mathrm{~s}, 1 \mathrm{H},-\mathrm{CH}), 6.73(\mathrm{~d}, 1 \mathrm{H}, J=7.9 \mathrm{~Hz}, \mathrm{Ar}-\mathrm{H}), 6.94-$ $7.07(\mathrm{~m}, 5 \mathrm{H}, \mathrm{Ar}-\mathrm{H}), 7.62\left(\mathrm{~s}, 2 \mathrm{H},-\mathrm{SO}_{2} \mathrm{NH}_{2}\right), 7.68(\mathrm{~d}, 2 \mathrm{H}, J=8.5 \mathrm{~Hz}$, $\mathrm{Ar}-\mathrm{H}), 8.04(\mathrm{~d}, 2 \mathrm{H}, J=8.5 \mathrm{~Hz}, \mathrm{Ar}-\mathrm{H}), 10.10(\mathrm{~s}, 1 \mathrm{H},-\mathrm{NH}) ;{ }^{13} \mathrm{C}$ NMR (75 MHz, DMSO- $\left.d_{6}\right) \delta(\mathrm{ppm}): 20.82,22.96,26.72,29.65$, 32.22 , 32.43, 41.46, 49.93, 113.29, 116.98, 119.47, 124.02, 127.73, $128.79,131.14,132.17,134.41,137.87,138.97,141.59,142.20$, 145.26, 147.58, 150.12, 195.35; HRMS (QTOF-ESI): $\mathrm{m} / \mathrm{z}$ calcd for $\mathrm{C}_{38} \mathrm{H}_{43} \mathrm{~N}_{3} \mathrm{O}_{6} \mathrm{~S}_{2}$ : 701.2593; found: $700.2733[\mathrm{M}-\mathrm{H}]^{-}$.

4.4.12. $N$-(3-(3,3,6,6-Tetramethyl-1,8-dioxo-10-(4-sulfamoylphenyl)-1,2,3,4,5,6,7,8,9,10-decahydroacridin-9-yl)phenyl)naphthalene-2-sulfonamide (61)

As white solid (ethanol), mp 207-208 ${ }^{\circ} \mathrm{C}$, yield 90\%. IR $\left(\mathrm{cm}^{-1}\right)$ : $3387 \mathrm{w}\left(-\mathrm{NH}_{2}\right), 3244 \mathrm{w}(-\mathrm{NH}), 3064 \mathrm{w}(\mathrm{Ar}-\mathrm{H}), 2958 \mathrm{w}(\mathrm{C}-\mathrm{H})$, $1632 \mathrm{~s}(\mathrm{C}=\mathrm{O}), 1585 \mathrm{~s}(\mathrm{C}=\mathrm{C}), 1334$ and $1156 \mathrm{~s}\left(\mathrm{SO}_{2}\right) ;{ }^{1} \mathrm{H}$ NMR $\left(300 \mathrm{MHz}, \mathrm{DMSO}-d_{6}\right) \delta(\mathrm{ppm}): 0.60\left(\mathrm{~s}, 6 \mathrm{H}, 2 \times-\mathrm{CH}_{3}\right), 0.80(\mathrm{~s}, 6 \mathrm{H}$, $\left.2 \times-\mathrm{CH}_{3}\right), 1.62\left(\mathrm{~d}, 2 \mathrm{H}, J=17.3 \mathrm{~Hz},-\mathrm{CH}_{2}\right), 1.88(\mathrm{~d}, 2 \mathrm{H}, J=16.0 \mathrm{~Hz}$, $\left.-\mathrm{CH}_{2}\right), 2.10-2.18\left(\mathrm{~m}, 4 \mathrm{H}, 2 \times-\mathrm{CH}_{2}\right), 4.95(\mathrm{~s}, 1 \mathrm{H},-\mathrm{CH}), 6.86(\mathrm{~d}$, $1 \mathrm{H}, J=7.9 \mathrm{~Hz}, \mathrm{Ar}-\mathrm{H}), 6.96-7.07(\mathrm{~m}, 2 \mathrm{H}, \mathrm{Ar}-\mathrm{H}), 7.23(\mathrm{~s}, 1 \mathrm{H}, \mathrm{Ar}-\mathrm{H})$, $7.63\left(\mathrm{~s}, 2 \mathrm{H},-\mathrm{SO}_{2} \mathrm{NH}_{2}\right), 7.58-7.75(\mathrm{~m}, 5 \mathrm{H}, \mathrm{Ar}-\mathrm{H}), 7.95-8.06(\mathrm{~m}, 5 \mathrm{H}$, $\mathrm{Ar}-\mathrm{H}), 8.33(\mathrm{~s}, 1 \mathrm{H}, \mathrm{Ar}-\mathrm{H}), 10.25(\mathrm{~s}, 1 \mathrm{H},-\mathrm{NH}) ;{ }^{13} \mathrm{C} \mathrm{NMR}(75 \mathrm{MHz}$, DMSO- $\left.d_{6}\right) \delta$ (ppm): 26.41, 29.61, 32.30, 32.37, 41.42, 49.88, 113.29, $118.40,119.93,122.39,124.33,127.76,127.99,128.11,128.25$, $128.92,129.27,129.68,131.10,131.96,134.65,137.12,137.94$, 141.56, 145.23, 147.56, 150.10, 195.34; HRMS (QTOF-ESI): $\mathrm{m} / \mathrm{z}$ calcd for $\mathrm{C}_{39} \mathrm{H}_{39} \mathrm{~N}_{3} \mathrm{O}_{6} \mathrm{~S}_{2}$ : 709.2280; found: $708.2390[\mathrm{M}-\mathrm{H}]^{-}$.

\subsection{CA inhibition}

An Applied Photophysics stopped-flow instrument has been used for assaying the CA catalyzed $\mathrm{CO} 2$ hydration activity by using method of Khalifah. ${ }^{33}$ Phenol red (at a concentration of $0.2 \mathrm{mM}$ ) has been used as indicator, working at the absorbance maximum of $557 \mathrm{~nm}$, with $20 \mathrm{mM}$ Hepes ( $\mathrm{pH} 7.5$ ) as buffer, and $20 \mathrm{mM} \mathrm{Na}_{2} \mathrm{SO}_{4}$ (for maintaining constant the ionic strength), following the initial rates of the $\mathrm{CA}$-catalyzed $\mathrm{CO}_{2}$ hydration reaction for a period of $10-100 \mathrm{~s}$. The $\mathrm{CO}_{2}$ concentrations ranged from 1.7 to $17 \mathrm{mM}$ for the determination of the kinetic parameters and inhibition constants. For each inhibitor at least six traces of the initial $5-10 \%$ of the reaction have been used for determining the initial velocity. The uncatalyzed rates were determined in the same manner and subtracted from the total observed rates. Stock solutions of inhibitor $(0.1 \mathrm{mM})$ were prepared in distilled-deionized water and dilutions up to $0.01 \mathrm{nM}$ were done thereafter with the assay buffer. Inhibitor and enzyme solutions were preincubated together for $15 \mathrm{~min}$ at room temperature prior to assay, in order to allow for the formation of the E-I complex. The inhibition constants were obtained by non-linear least-squares methods using PRISM (www.graphpad.com), and non-linear least squares methods, values representing the mean of at least three different determinations, as described earlier by us. ${ }^{35,36}$ All enzymes used were recombinant ones, produced in Escherichia coli as reported earlier. ${ }^{37,38}$ CA IX and XII were the catalytic domain only. The concentrations of the enzymes in the assay system were: $11.4 \mathrm{nM}$ for hCA I; $7.5 \mathrm{nM}$ for hCA II, $8.6 \mathrm{nM}$ for hCA IX and $10.6 \mathrm{nM}$ for hCA XII, respectively.

\section{Acknowledgements}

This research was financed in part by Dumlupınar University Research Fund (Grant No. 2012-38) and by an EU FP7 Project (Dynano). 


\section{Supplementary data}

Supplementary data associated with this article can be found, in the online version, at http://dx.doi.org/10.1016/j.bmc.2015.09.022.

\section{References and notes}

1. Singh, S.; Chhina, S.; Sharma, V. K.; Sachdev, S. S. J. Chem Soc., Chem. Commun. 1982, 453.

2. Kim, J. P.; Kim, W. G.; Koshino, H.; Jung, J.; Yoo, I. Phytochemistry 1996, 43, 425.

3. Gamage, S. A.; Spicer, J. A.; Atwell, G. J.; Finlay, G. J.; Baguley, B. C.; Denny, W. A. J. Med. Chem. 1999, 42, 2383.

4. Pitta, M. G. D.; Souza, E. S.; Barros, F. W. A.; Filho, M. O.; Pessoa, C. O Hernandes, M. Z: Lima, M. D. A.; Galdino, S. L.; Pitta, I. D. Med. Chem. Res. 2013. 22, 2421.

5. Kawle, P. R.; Deohate, P. P.; Berad, B. N.; Srivastava, K. K.; Sharma, P. Indian J. Chem., Sect. B: Org. Chem. Incl. Med. Chem. 2013, 52, 1531.

6. Berkan, Ö.; Saraç, B.; Simsek, R.; Yıldırım, S.; Sarıoğlu, Y.; Safak, C. Eur. J. Med. Chem. 2002, 37, 519.

7. Fu, X. J.; Fang, Y.; Fang, M. Biomed. Res. Int. 2013, 1.

8. Hamulakovaa, S.; Imricha, J.; Janoveca, L.; Kristiana, P.; Danihela, I.; Holasb, O.; Pohankac, M.; Böhmd, S.; Kozurkovaa, M.; Kuca, K. Int. J. Biol. Macromol. 2014, $70,435$.

9. Kaur, J.; Singh, P. Expert Opin. Ther. Patents 2011, 21, 437.

10. Zhang, B.; Li, X.; Li, B.; Gao, C.; Jiang, Y. Expert Opin. Ther. Patents 2014, 24, 647.

11. Kaya, M.; Başar, E.; Çakir, E.; Tunca, E.; Bülbül, M. J. Enzyme Inhib. Med. Chem. 2012, 27, 509.

12. Ulus, R.; Yesildağ, İ.; Tanç, M.; Bülbül, M.; Kaya, M.; Supuran, C. T. Bioorg. Med. Chem. 2013, 21, 5799.

13. (a) Supuran, C. T. Nat. Rev. Drug Disc. 2008, 7, 168; (b) Supuran, C. T. J. Enzyme Inhib. Med. Chem. 2013, 28, 229.

14. Neri, D.; Supuran, C. T. Nat. Rev. Drug Disc. 2011, 10, 767.

15. Alterio, V.; Di Fiore, A.; D’Ambrosio, K.; Supuran, C. T.; De Simone, G. Chem. Rev. 2012, 112, 4421.

16. (a) Aggarwal, M.; McKenna, R. Expert Opin. Ther. Patents 2012, 22, 903; (b) Arechederra, R. L.; Waheed, A.; Sly, W. S.; Supuran, C. T.; Minteer, S. D. Bioorg. Med. Chem. 2013, 21, 1544; (c) Scozzafava, A.; Supuran, C. T.; Carta, F. Expert Opin. Ther. Patents 2013, 23, 725; (d) Harju, A. K.: Bootorabi, F.; Kuuslahti, M. Supuran, C. T.; Parkkila, S. J. Enzyme Inhib. Med. Chem. 2013, 28, 231; (e) Supuran, C. T. Expert Opin. Ther. Patents 2003, 13, 1545; (f) De Simone, G.; Supuran, C. T. Curr. Top. Med. Chem. 2007, 7, 879; (g) Supuran, C. T.; Di Fiore, A. De Simone, G. Expert Opin. Emerg. Drugs 2008, 13, 383; (h) Scozzafava, A. Supuran, C. T.; Carta, F. Expert Opin. Ther. Patents 2013, 23, 725.

17. (a) Supuran, C. T. J. Enzyme Inhib. Med. Chem. 2012, 27, 759; (b) Aggarwal, M.; Boone, C. D.; Kondeti, B.; McKenna, R. J. Enzyme Inhib. Med. Chem. 2013, 28, 267; (c) Winum, J. Y.; Supuran, C. T. J. Enzyme Inhib. Med. Chem. 2015, 30, 321; (d) Capasso, C.; Supuran, C. T. J. Enzyme Inhib. Med. Chem. 2015, 30, 325.

18. (a) Alterio, V.; Hilvo, M.; Di Fiore, A.; Supuran, C. T.; Pan, P.; Parkkila, S.; Scaloni, A.; Pastorek, J.; Pastorekova, S.; Pedone, C.; Scozzafava, A.; Monti, S. M.; De
Simone, G. Proc. Natl. Acad. Sci. U.S.A. 2009, 106, 16233; (b) Touisni, N.; Maresca, A.: McDonald, P. C.; Lou, Y.; Scozzafava, A.; Dedhar, S.; Winum, J. Y.; Supuran, C. T. J. Med. Chem. 2011, 54, 8271; (c) Bonneau, A.; Maresca, A.; Winum, J. Y.; Supuran, C. T. J. Enzyme Inhib. Med. Chem. 2013, 28, 397; (d) Sharma, A.; Tiwari, M.; Supuran, C. T. J. Enzyme Inhib. Med. Chem. 2014, 29, 292.

19. (a) Pacchiano, F.; Carta, F.; McDonald, P. C.; Lou, Y.; Vullo, D.; Scozzafava, A.; Dedhar, S.; Supuran, C. T. J. Med. Chem. 2011, 54, 1896; (b) Lou, Y.; McDonald, P. C.; Oloumi, A.; Chia, S. K.; Ostlund, C.; Ahmadi, A.; Kyle, A.; Auf dem Keller, U.; Leung S.; Huntsman, D. G.; Clarke, B.; Sutherland, B. W.; Waterhouse, D.; Bally, M. B.; Roskelley, C. D.; Overall, C. M.; Minchinton, A.; Pacchiano, F.; Carta, F. Scozzafava, A.; Touisni, N.; Winum, J. Y.; Supuran, C. T.; Dedhar, S. Cancer Res. 2011, 71, 3364; (c) Krall, N.; Pretto, F.; Decurtins, W.; Bernardes, G. J. L.; Supuran, C. T.; Neri, D. Angew. Chem., Int. Ed. 2014, 53, 4231; (d) Gieling, R. G.; Parker, C. A.; De Costa, L. A.; Robertson, N.; Harris, A. L.; Stratford, I. J.; Williams, K. J. J. Enzyme Inhib. Med. Chem. 2013, 28, 360.

20. (a) Supuran, C. T. Future Med. Chem. 2011, 3, 1165; (b) Supuran, C. T. Bioorg. Med. Chem. Lett. 2010, 20, 3467; (c) Nishimori, I.; Onishi, S.; Takeuchi, H.; Supuran, C. T. Curr. Pharm. Des. 2008, 14, 622.

21. Supuran, C. T.: Scozzafava, A.; Casini, A. Med. Res. Rev. 2003, 23, 146.

22. Supuran, C. T.; Scozzafava, A.; Casini, C. T. Development of Sulfonamide Carbonic Anhydrase Inhibitors (CAIs). In Carbonic Anhydrase-Its Inhibitors and Activators; Supuran, C. T., Scozzafava, A., Conway, J., Eds.; CRC Press: Boca Raton (FL), 2004; pp 67-147.

23. Carta, F.; Temperini, C.; Innocenti, A.; Scozzafava, A.; Kaila, K.; Supuran, C. T. J Med. Chem. 2010, 53, 5511.

24. Innocenti, A.; Vullo, D.: Scozzafava, A.; Supuran, C. T. Bioorg. Med. Chem. 2008 $16,7424$.

25. Maresca, A.; Carta, F.; Vullo, D.; Supuran, C. T. J. Enzyme Inhib. Med. Chem. 2013 $28,407$.

26. Carta, F.; Akdemir, A.; Scozzafava, A.; Masini, E.; Supuran, C. T. J. Med. Chem 2013, 56, 4691

27. Maresca, A.; Temperini, C.; Pochet, L.; Masereel, B.; Scozzafava, A.; Supuran, C. T. J. Med. Chem. 2010, 53, 335.

28. Carta, F.; Maresca, A.; Scozzafava, A.; Supuran, C. T. Bioorg. Med. Chem. 2012, 20, 2266.

29. Carta, F.; Vullo, D.; Maresca, A. O.; Scozzafava, A.; Supuran, C. T. Bioorg. Med Chem. Lett. 2012, 22, 2182.

30. Li, S.; Ding, S.; Xu, S.; Zhang, J.; Wang, S.; Zhou, C.; Li, X. Res. Chem. Intermed. 2014, 40, 2091.

31. Kaya, M.: Demir, E.; Bekci, H. J. Enzyme Inhib. Med. Chem. 2013, 28, 885.

32. Ulus, R.; Yeșildağ, İ.; Elmastaș, M.; Kaya, M. Med. Chem. Res. 2015, 24, 3752.

33. Pamuk, H.; Aday, B.; Sen, F.; Kaya, M. RSC Adv. 2015, 5, 49295.

34. Khalifah, R. J. J. Biol. Chem. 1971, 246, 2561.

35. Maresca, A.; Vullo, D.; Scozzafava, A.; Manole, G.; Supuran, C. T. J. Enzyme Inhib. Med. Chem. 2013, 28, 392.

36. Maresca, A.; Scozzafava, A.; Vullo, D.; Supuran, C. T. J. Enzyme Inhib. Med. Chem 2013, 28, 384

37. Scozzafava, A.; Menabuoni, L.; Mincione, F.; Mincione, G.; Supuran, C. T. Bioorg. Med. Chem. Lett. 2001, 11, 575.

38. Vomasta, D.; Innocenti, A.; König, B.; Supuran, C. T. Bioorg. Med. Chem. Lett. 2009, 19, 1283. 